\title{
2000 ピン級FC-BGAの実装信頼性評価
}

\author{
吳 強 ${ }^{*}$, 馬場 伸治 ${ }^{*}$, 松嶋 弘倫 ${ }^{*}$, 原田 耕三* ${ }^{*}$, 林 英二*，木村 通孝*
}

\section{Reliability Study for 2000 Pin Class Flip-Chip BGA}

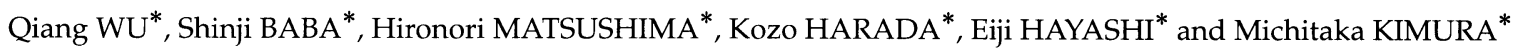

*三菱電機株式会社半導体生産・技術統括部アセンブリ技術部（テ664-0005＼cjkstart兵庫県伊丹市瑞原 4-1）

* Assembly Engineering Dept., Manufacturing Technology \& Production Management Div., Mitsubishi Electric Corp. (4-1 Mizuhara, Itami-shi, Hyogo 664-0005)

\begin{abstract}
This study has investigated the solder joint reliability for 2000 pin class Flip-chip BGA (FC-BGA) mounted on PCB (printed circuit board), through the thermal cycle evaluation and FEM (Finite Element Method) analysis. Owing to the stress of Z-axis direction, the fracture occurred at the solder ball under the chip area of FC-BGA. It is assumed that one key factor determining solder joint life is the initial deformation of FC-BGA after mounting on the PCB. Increasing the stiffness of FC-BGA enable to decrease the initial deformation, so that it improves the solder joint reliability. In addition, in the case of high-density mounting, the solder joint reliability mounted on the reworked PCB shows negative result, caused by the reworking temperature.
\end{abstract}

Key Words: FC-BGA, Reliability, Z-axis Stress, Warpage, Deformation, Rework

\section{1.はじめに}

電子機器の高性能化・高機能化の進展に伴い, 多ピン 化, 高放熱, 高速動作に優れた半導体パッケージとして Flip-Chip BGA (FC-BGA) が注目されている。この多ピン化 に伴い，パッケージサイズも大型化してきており，パッ ケージ外部端子（はんだボール）の実装ボードとの接続部 信頼性の確保は, 重要な技術的課題の 1 つとなっている。 大型サイズの FC-BGAでは, 半導体チップと BGA 基板が接 合するバンプ（1st 接合部）は，アンダーフィル樹脂で補 強することによって, 接続信頼性が十分に確保されている 反面, 実装ボードと接続するはんだボール（2nd 接合部） は, チップとFC-BGA 基板との熱膨張係数の差や, アン ダーフィル樹脂の収縮などによるパッケージ反りの影響で, はんだボール部分の歪みが大きくなるため, 破断に至る寿 命を確保する技術的な改善が必要である ${ }^{1,2)}$ 。この破断原因 の解明は, FC-BGAの高信頼性を達成する上で, 重要なポ イントである。

本稿では，このFC-BGAにおけるパッケージ反りによる 2nd 接合部の応力挙動を明確化するために, 2000 pin 級 FCBGA の実装信頼性の評価・解析および 3 次元 FEM (Finite Element Analysis Method)解析を行い, 2nd 接合部の不良発 生箇所および発生原因について評価した結果を報告する。 さらに，実装プロセスで行われるリワーク作業を想定した サンプルを作成し，実装信頼性への影響についても評価を 行った。

\section{2. 評価方法}

\section{1 評価仕様}

Fig. 1 に, FC-BGAの写真と断面構造図を示す。また, Table 1 に, 今回の評価で用いた 1848 ピン FC-BGA と実装 ボードの仕様を示す。

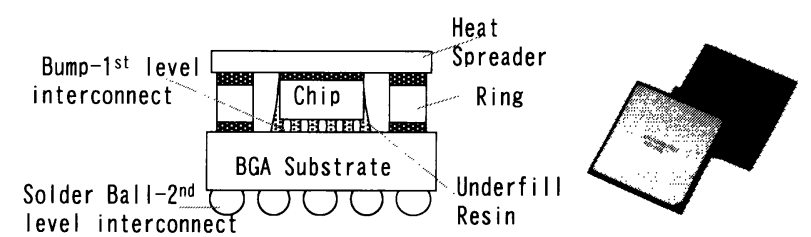

Fig. 1 Cross-sectional structure of FC-BGA

Table 1. Shape and size of FC-BGA

\begin{tabular}{c|c|c|c|c|c|c|c|c}
\hline \multicolumn{5}{c|}{ FC-BGA PKG Spec. } & \multicolumn{3}{c}{ Board Spec. } \\
\hline Pin Numbers & $\begin{array}{c}\text { PKG Size } \\
(\mathrm{mm} \square)\end{array}$ & $\begin{array}{c}\text { Chip Size } \\
(\mathrm{mm} \square)\end{array}$ & $\begin{array}{c}\text { Ball Pitch } \\
(\mathrm{mm})\end{array}$ & Ball Layout & $\begin{array}{c}\text { Ball Layout } \\
\text { under Die }\end{array}$ & $\begin{array}{c}\text { Size } \\
(\mathrm{mm})\end{array}$ & $\begin{array}{c}\text { Thickness } \\
(\mathrm{mm})\end{array}$ & Pad Type \\
\hline 1848 & 45.0 & 16.5 & 1.0 & $43 \times 43$ & $17 \times 17$ & $250 \times 250$ & 2.8 & $\begin{array}{c}\phi 0.45 \mathrm{~mm}, \\
\text { N-SMD }\end{array}$ \\
\hline
\end{tabular}


FC-BGA は，実装信頼性を向上させるため，実装ボード と同等材料であるエポキシ樹脂をベースとする有機ビルド アップ基板を採用し，実装ボードとの接合には $63 \mathrm{Sn}-37 \mathrm{~Pb}$ の共晶はんだボールを使用している。また，はんだ接合 パッドの表面処理は, $\mathrm{Cu}$ パッド上に $\mathrm{Ni} / \mathrm{Au}$ の 2 層無電解 めっきを採用し，はんだとの接合を最適とする処理によっ て初期接合信頼性を確保している3),4)。

実装ボードは, $2.8 \mathrm{~mm}$ 厚の高 $\mathrm{Tg}$ の FR4 基板を使用した， $\mathrm{Cu}$ パッド部はプリフラックスの表面処理を行っている。

FC-BGAの実装は N2リフロー炉を用い $\max .225^{\circ} \mathrm{C}$ の温度 条件で行い，実装後に，X線観察および断面観察より初期 接合性が問題ないことを確認した上で温度サイクル試験に 投入した。

Fig. 2 に，ボード実装したFC-BGA の配置図, Table 2 に, 評価仕様を示す。

FC-BGAの構造については，反りを低減し，実装信頼性 を高めるため, ヒートスプレッダを厚く高剛性（Hタイプ） にしているが，その信頼性への影響を確認するため，ヒ一 トスプレッダを薄くした低剛性（Lタイプ）でも評価を行っ た。

ボードについては，実装ボード1枚に 1848 ピン FC-BGA を 8 個， $5 \mathrm{~mm}$ 間隔で実装した。リワークの影響を確認する ため, リワークなしの A ボードとリワークありの Bボード を評価した。

以上より, 評価仕様としては, $\mathrm{AH}$ 仕様（リワークなし， 高剛性ヒートスプレッダ, FC-BGA8個実装), AL 仕様（リ ワークなし，低剛性ヒートスプレッダ, FC-BGA8個実装), BL 仕様（AL 仕様と同一の FC-BGA 仕様, No. 5 No. 8 の FC-BGAをリワーク実施し，リワークをしていないNo. $1 \sim$ No. 4 の FC-BGA を計 20 個評価）の 3 通りについて評価 した。リワーク中の最高温度はN2リフローのプロセスと 同様に約 $225^{\circ} \mathrm{C}$ に調整した。

\section{2 実装信頼性試験方法}

評価条件は, $0^{\circ} \mathrm{C} \sim 100^{\circ} \mathrm{C}, 38 \mathrm{~min} /$ cycle で行った，昇

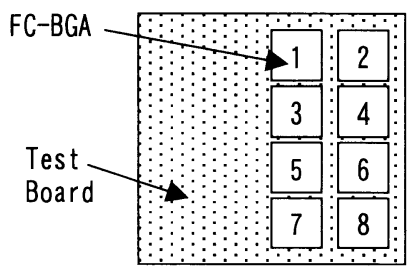

Fig. 2 Location of FC-BGA mounted on the test board

Table 2. Evaluating sample type of 1848 pin FC-BGA

\begin{tabular}{c|c|c|c|c}
\hline Sample & $\begin{array}{c}\text { FC-BGA } \\
\text { Numbers }\end{array}$ & Board & $\begin{array}{c}\text { FC-BGA } \\
\text { Type }\end{array}$ & $\begin{array}{c}\text { FC-BGA } \\
\text { Status }\end{array}$ \\
\cline { 1 - 2 } $\mathrm{AH}$ & $8 \times 1$ Board & \multirow{2}{*}{ A (Non-Rework) } & H (High Stiffness) & \multirow{2}{*}{ L (Low Stiffness) } \\
\cline { 1 - 2 } AL & $8 \times 1$ Board & & \\
\hline BL & $4 \times 5$ Board & B (With Rework) & & \\
\hline
\end{tabular}

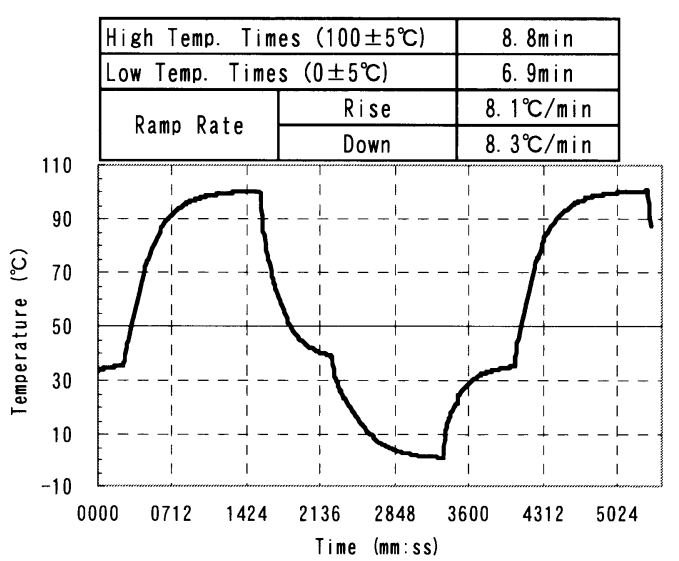

Fig. 3 Temperature profile of thermal cycle test

温・降温プロファイルをFig. 3 に示す。試験中，評価ボー ド上の試験温度および各試験 FC-BGAのはんだボール部分 の抵抗值を常時モニタし, 初期抵抗值から2 倍以上変化し たものを不良と判定した。

\section{3 はんだ破断部の解析方法}

試験後に，断面観察による破断詳細箇所の分析および浸 透液処理によるクラック発生形状のチェックを実施した。 さらに, 実評価結果に対し，3次元FEM分析にて弾塑性体 としてのはんだ応力検証を行った。その結果は 3.4 節にて 記述する。

\section{FC-BGA 構造の影響}

\section{1 実装信頼性結果}

Fig. 4 に, AH, AL, BL 3 仕様の温度サイクル試験結果の ワイブル図を示す。一般的に信頼性評価は，ワイブル故障 分布関数 $\mathrm{F}(\mathrm{x})=1-\exp \left[-(\mathrm{x} / \alpha)^{\beta}\right]$ で表される。ここで， $\alpha$ は故 障状態を表す形状係数， $\beta$ は不良発生率が $62.3 \%$ での特性 寿命を示す。Fig. 4 にワイブル分布関数より求めた，初期 寿命 $(0.1 \%$ 不良のサイクル数） と特性寿命（63.2\%不良の サイクル数）を示した。

Fig. 4 より，FC-BGA 剛性の実装信頼性への影響につい て, 特性寿命は, 剛性を高めたFC-BGAを実装した AH仕 様が 4151 サイクルであるが，剛性の低いFC-BGA を実装し た AL仕様では，2759サイクルに劣化することがわかる。 剛性が高い方は信頼性が高い。文献)にて報告されている ように，ヒートスプレッダ厚さの調整による FC-BGA 剛性 の変化は, 実装サイクル信頼性への影響が大きいことが確 認された。

次に $\mathrm{AH}, \mathrm{AL}$ 仕様のはんだボールの破断箇所を Fig. 5 に示 す。Fig. 5(a)に示すようにFC-BGA のボール配置はフルアレ イタイプでX, Y 軸方向に対称性がある。また，破断箇所は チップ直下ボールのみである。そこで, Fig. 5(b), (c)にチッ プ直下の $1 / 8$ エリアにまとめて表示した。高剛性 FC-BGA (AH) は，3〜6列目に分散してボール破断が発生しているが, 中心より 4 6列目が比較的に多く, また, 低剛性FC-BGA 


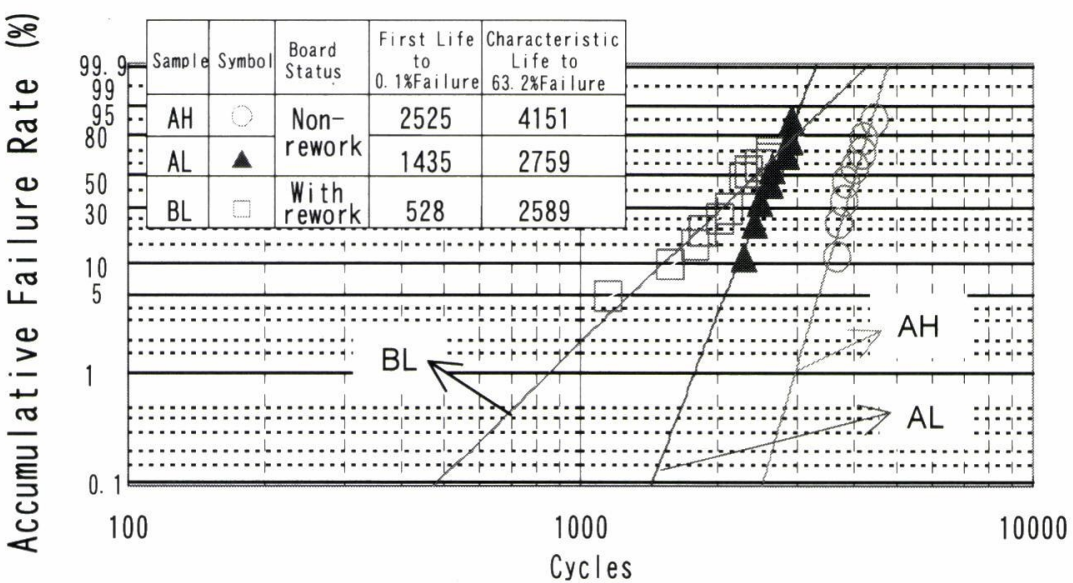

Fig. 4 Solder joint reliability

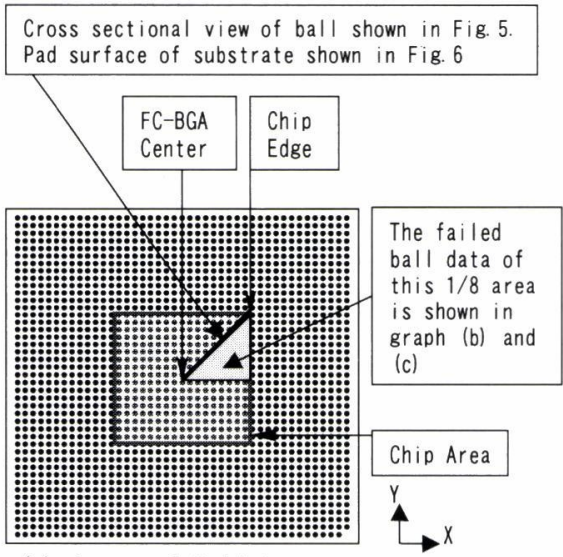

(a) : Image of Ball Layout

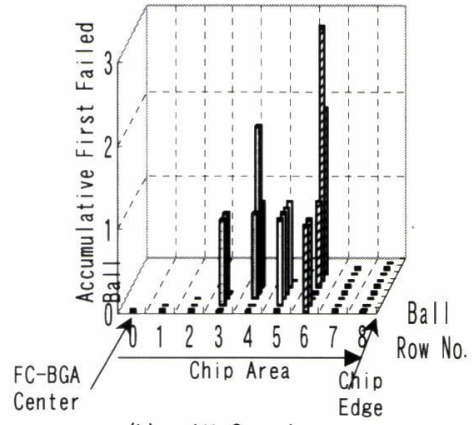

(b) : AH Sample

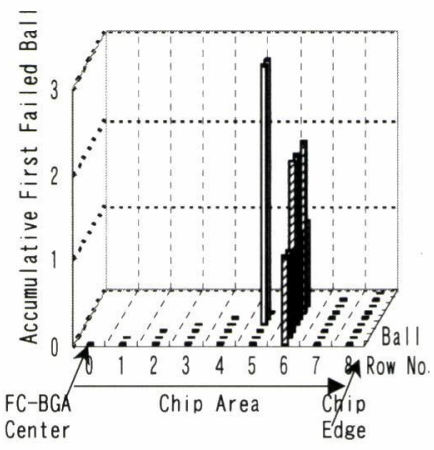

(c): AL Sample

Fig. 5 First failed ball distribution under $1 / 8$ chip area

(AL) も5 6 列目に集中している。一般に，パッケージサイ ズが大きいほど, パッケージコーナ部のボールにかかるせ ん断応力が大きくなるが6), FC-BGAでは, チップと FC$\mathrm{BGA}$ 基板との熱膨張の差およびアンダーフィル樹脂の収縮 などによる反りの影響で，チップ外周領域の直下面にある はんだボールが破断しやすい。

\section{2 はんだボール破断部の解析}

Fig. 6 に温度サイクル試験後のはんだボール破断箇所の 断面写真を示す。Fig. 7 は試験後に浸透液処理したFC-BGA をボードからはがした後の FC-BGA 基板パッド部のクラッ ク発生状態を示している。破断筒所はFC-BGAパッケージ 側のはんだ内に集中している。これは今回実装ボード側の パッド構造がN-SMDであり, SMD 構造としたFC-BGA 側に
比べて接合強度が大きいためと考えられる。破断クラック 状態については，Fig. 6 およびFig. 7 より，はんだボールの チップ中心側から発生し，チップエッジ側方向へ偏心円状 に進展することが判明した。

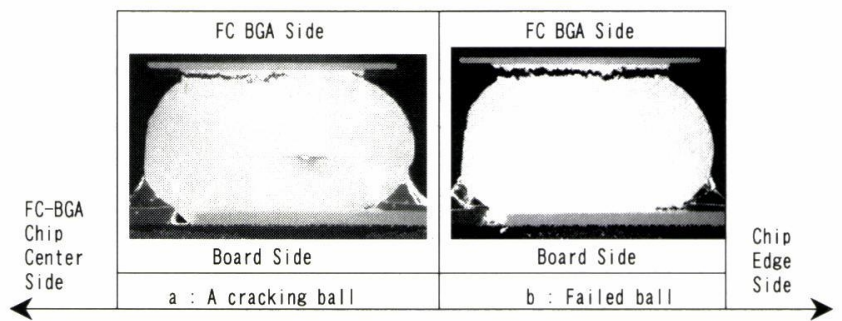

Fig. 6 Cross-section SEM of solder fatigue at the first failure point

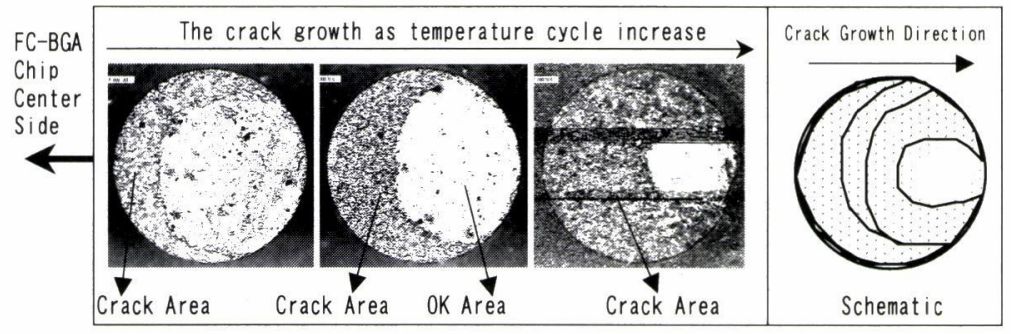

Fig. 7 Crack growth on FC-BGA pad 


\section{3 破断原因の分析}

さらに，破断原因を明確にするために，実装する前後の FC-BGA の反り状態について調べた。

Fig. 8 に，3次元測定機によるLタイプの対角線方向の ボールパッド面の反り実測結果, および $\mathrm{H}, \mathrm{L}$ タイプの各温 度点での反り最大量を示している。H, Lタイプの反り挙動 は, 同一傾向で, 常温状態でチップ側凸の方向であるが, 温度上昇に伴い減少している。反り最大量は $\mathrm{H}$ タイプの方 が小さい。 $25^{\circ} \mathrm{C}$ から $115^{\circ} \mathrm{C}$ 間の反り変化量は $\mathrm{H}, \mathrm{L}$ タイプ の差がなく，共に $105 \mu \mathrm{m}$ 程度減少している。

Fig. 9 は, 実装直後と温度サイクル (TCY) 完了後の FCBGA およびボードのパッド位置の高さ分布を示す。なお， 温度サイクル完了後のサンプルは最初の破断発生後, さら に約 600 サイクルを付加し, チップ直下のボール全部を破 断させている。Fig. 9より, ボードパッド位置の高さ分布 については，温度サイクル試験による影響がほとんどなく， 共にわずかな凸状となっている。一方，FC-BGA 基板パッ ド位置の高さ分布については, FC-BGA の反りがFig. 8に示 すように温度上昇に伴い減少するため, 実装直後の FC-

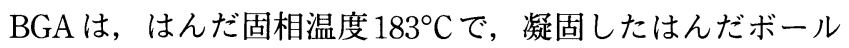
の拘束によって $183^{\circ} \mathrm{C}$ のほぼフラット形状に固定されてい

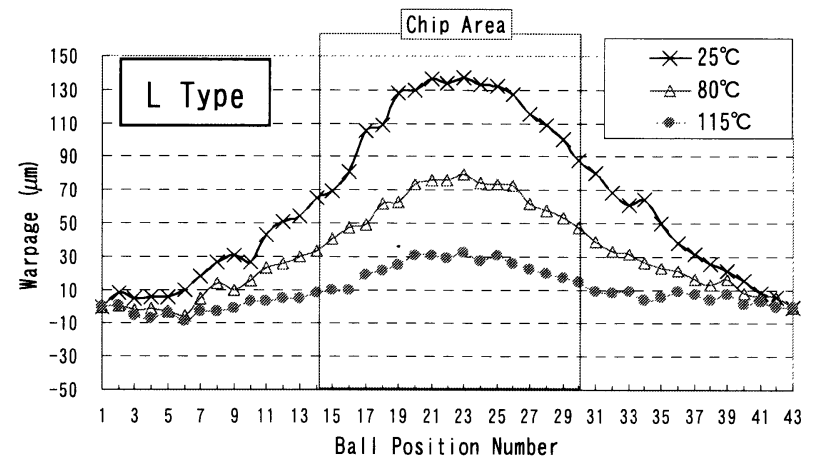

\begin{tabular}{|l|c|c|c|}
\cline { 2 - 4 } \multicolumn{1}{c|}{} & \multicolumn{3}{c|}{ max. Warpage $(\mu \mathrm{m})$} \\
\cline { 2 - 4 } \multicolumn{1}{c|}{} & $25^{\circ} \mathrm{C}$ & $80^{\circ} \mathrm{C}$ & $115^{\circ} \mathrm{C}$ \\
\hline L Type & 137.0 & 79.5 & 32.2 \\
\hline H Type & 125.3 & 62.2 & 20.4 \\
\hline
\end{tabular}

Fig. 8 FC-BGA warpage on ball pad side for $H$ and $L$ type samples

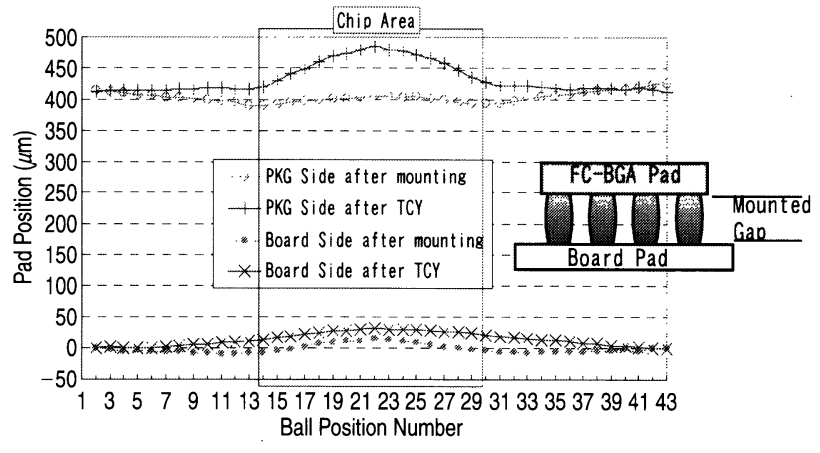

Fig. 9 Pad position of board and FC-BGA
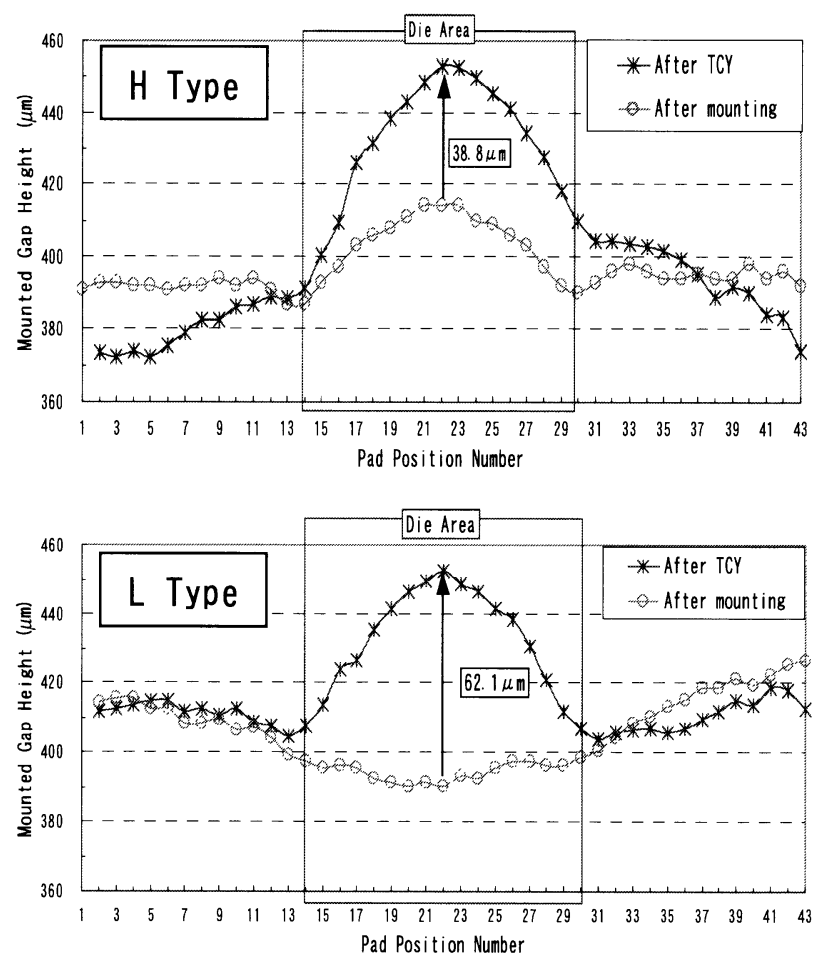

Fig. 10 Mounted gap height distribution

る。次にチップ直下のボールを全部破断させた温度サイク ル完了後は, FC-BGAの中央部が開放され, FC-BGA 単体 の $25^{\circ} \mathrm{C}$ での反り形状に戻り凸状となった。以上より，FCBGA 実装においては, 実装直後のはんだボールにZ 軸方向 の引張残留応力が存在していると考えられる。

次に，実装直後の FC-BGA反りの矯正量之実装信頼性寿 命との関連性を検証するため, 実装直後および温度サイク ル完了後（ボール破断後）に, サンプルの実装高さ変化を 解析した。その結果をFig. 10 に示す。実装高さはFC-BGA 基板パッドと実装ボードパッド間との距離を指す。実装直 後の実装高さは，Hタイプの方がLタイプより，特にチッ プ直下の領域が高くなっている。このため, ボール破断後 の FC-BGA 中心部の実装高さ変化量はL タイプの $62.1 \mu \mathrm{m}$ に 比べ, $\mathrm{H}$ タイプが $38.8 \mu \mathrm{m}$ と小さくなっている。この変化量 が実装直後の FC-BGA 反りの矯正量に相当し, Hタイプで

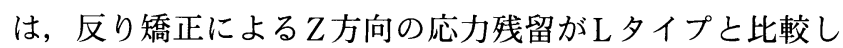
て小さいため，Fig.4に示したように信頼性寿命が長くなっ たと考えられる。

\section{4 破断箇所と歪み分布のシミュレーション解析}

試験および解析結果を検証するために, 有限要素法 (FEM)を用いた応力シミュレーション解析を行った。材料 モデルは, はんだ部の応力および応力の最大箇所を比較す る目的で, はんだを弾塑性材料とし, その他材料を弾性材 料として扱った。解析に用いた材料物性值を Table 3 に 示す。 $\mathrm{Sn}-\mathrm{Pb}$ はんだの非線形性については, $100^{\circ} \mathrm{C}$ (試験 最高温度), $2400 \mathrm{sec} / \mathrm{cycle}$ (試験周波数) の応力一歪み曲 線を利用した。熱応力解析は, はんだ歪みの振る舞いが 2 サイクル目から安定しているため, 2 サイクル目に対して 
Table 3. Material properties

\begin{tabular}{l|c|c|c}
\cline { 2 - 4 } & $\begin{array}{c}\text { Elastic modulus } \\
\left(\mathrm{Kgf} / \mathrm{mm}^{2}\right)\end{array}$ & $\begin{array}{c}\text { TCE } \\
\left(\mathrm{ppm} /{ }^{\circ} \mathrm{C}\right)\end{array}$ & $\begin{array}{c}\text { Poisson } \\
\text { ratio }\end{array}$ \\
\hline Chip & 19000 & 3.6 & 0.3 \\
\hline Underfill resin & 810 & 27 & 0.35 \\
\hline PKG substrate & 2950 & 19 & 0.3 \\
\hline PWB board & 1800 & 16.7 & 0.18 \\
\hline Sn-Pb solder & 2176 & 24.5 & 0.36 \\
\hline Ring & 13000 & 17 & 0.3 \\
\hline Heat spreader $(\mathrm{H} / \mathrm{S})$ & 12300 & 17.7 & 0.3 \\
\hline
\end{tabular}

行った

温度サイクル評価においては，PKG/実装ボード間の熱 膨張係数差によるX-Y 面のせん断応力と, 反りの温度変化 によるZ 方向の応力が同時に存在している。 $\mathrm{X}-\mathrm{Y}$ 面のせん 断応力は, 傾向的に, $\Delta \gamma \fallingdotseq\left\{(\mathrm{A} \times \mathrm{L})^{2}+\mathrm{B}^{2}\right\}^{1 / 2}$ と表示できる6)。 Lは，はんだボールをパッケージ中心との距離，A と B は 熱膨張係数差および評価温度範囲を示す定数である。この ため，X-Y面のせん断応力が支配的に働いた場合に，パッ ケージコーナ部のボールは, Lが最大のポイントで最初に 破壊する。これは, ベアチップ実装やWLCSP実装の場合 に一般的である ${ }^{8), 99}$ 。

しかし, FC-BGAの場合では, Fig. 5 に示すように, パッ ケージ中央部のボールが最初に破壊した。支配的な破壊応 力は, X-Y面のせん断応力ではなく, 反り変化 (Fig. 8) で発 生するZ方向の応力と考えられる。そこで，この反り変化 のはんだボール部への影響を確認する目的として，Z方向 のみの応力解析を行った。

まずは，FC-BGA反り変化の影響を明白化するため，実 装ボードのZ方向変化がなしと仮定した。Fig. 11 に(a) FEM モデルの側面図, および $\Delta \mathrm{T}=50^{\circ} \mathrm{C}$ の (b) 昇温状態と (c) 降温 状態の解析結果を示す。チップ直下以外のボール変化につ いては, 昇温状態と降温状態は共に均一で差がなく，Z方 向の応力差がほぼない。一方, チップ直下のボールについ ては，昇温状態はボールが圧縮され，降温状態はボールが 引っ張られ，大きな Z方向の応力が存在していることが判 明した。本解析モデルで FC-BGA 単体の初期反りを $0 \mu \mathrm{m}$ と 仮定したことで, Fig. 8に示した温度変化に伴いFC-BGA反

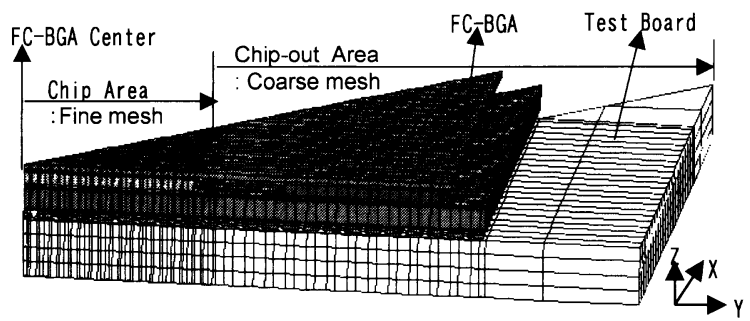

(a) : Model aspect

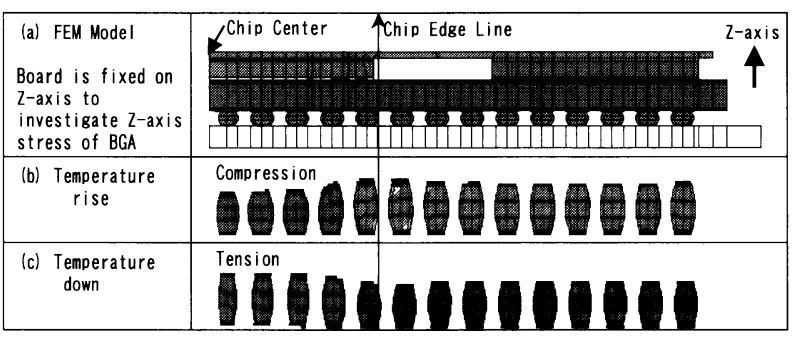

Fig. 11 Z-axis stress for low-pin-count FC-BGA

り量の減少および増加が Fig. 11 に示したはんだボールへの 圧縮および引張りに相当することより，Z方向の応力が FCBGA 反りの温度変化量に対応することを見出した。

次に, Z方向の応力が温度サイクル試験で発生した破断 箇所 (Fig. 5b, c) との相関を検証するために, H とLタイプ FC-BGAに対し, Fig. 12 に示した1/8モデルで, 3D-FEM解 析を行った。0 100 ${ }^{\circ} \mathrm{C} / \mathrm{cycle}$ の試験条件において, 解析に は初期温度を $50^{\circ} \mathrm{C}$, 温度変化量 $\Delta \mathrm{T}$ を $50^{\circ} \mathrm{C}$ (昇温が $50^{\circ} \mathrm{C}$ $\rightarrow 100^{\circ} \mathrm{C}$, 降温が $50^{\circ} \mathrm{C} \rightarrow 0^{\circ} \mathrm{C}$ ) と設定した。3D の $1 / 8$ モデ ルはFC-BGA 中心部の $\mathrm{X}, \mathrm{Y}$ 方向を固定し, 実装直後の FC$\mathrm{BGA}$ 単体の反り矯正を無視し， $50^{\circ} \mathrm{C}$ での初期反りを $0 \mu \mathrm{m}$ とした。メッシュ仕様に関しては, Fig. 12(a)に示すように, チップエリア +1 列ボールの範囲に細かいメッシュで, そ れ以外のエリアは粗いメッシュでモデル化した。チップエ リアおよびはんだボールのメッシュの詳細図はFig. 12(b), (c) に示している。破断がチップ直下のみに発生し, 引張りと 圧縮の応力屯対称的であるため, FEM解析で得た応力分布 図および応力データグラフは, 引張応力が発生する降温状 態，かつチップ直下 $1 / 8$ エリアのみを表示した。

Fig. 13 はFC-BGAのはんだボールに関する，Z方向応力 の (a) 面分布㧍よび (b) H タイプ, (c) L タイプをデータ化し たVon-Mises 応力の分布図である。応力分布においては, $\mathrm{H}, \mathrm{L}$ タイプともに中心より $4 \rightarrow 6$ 列目の応力値が高く, Fig. 5 に示した評価での破断箇所とほぼ一致し, $Z$ 方向の応力 が破壊の主因と考えられる。しかし，応力の值に関しては, 両タイプとも同じである。したがって，H, Lタイプの実装 サイクル寿命差 (Fig. 4) の起因は, 温度サイクル中で発生し たZ方向応力 (Fig. 13)より屯，パッケージ実装直後に発生 した反り矯正量の差(Fig. 10)にあると推定できる。この反 りの矯正ははんだボール凝固時の初期残留応力に相当でき, よって，FC-BGA 信頼性予測のために相当歪み範囲の解析

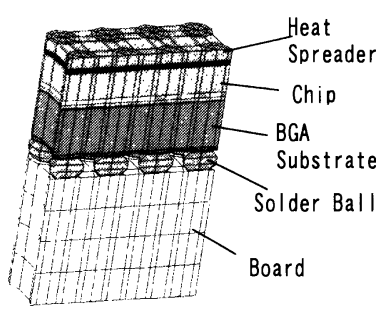

(b): Fine mesh under chip

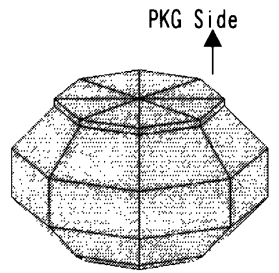

(c) : Ball mesh at PKG

Fig. 12 3D-FEM model for $1 / 8$ area 


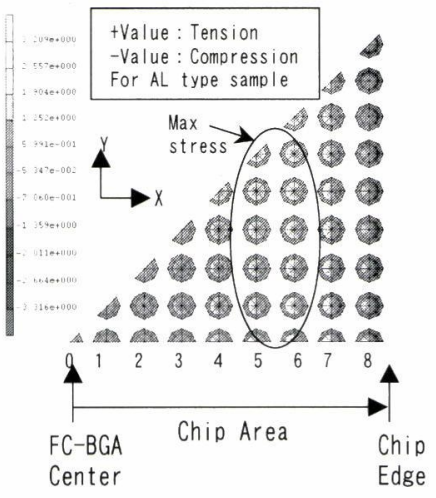

(a): Stress Distribution as Temperature Down

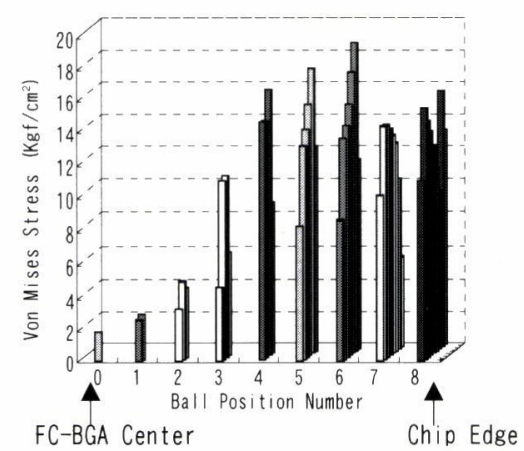

(b) : Tensile Stress of High AH sample

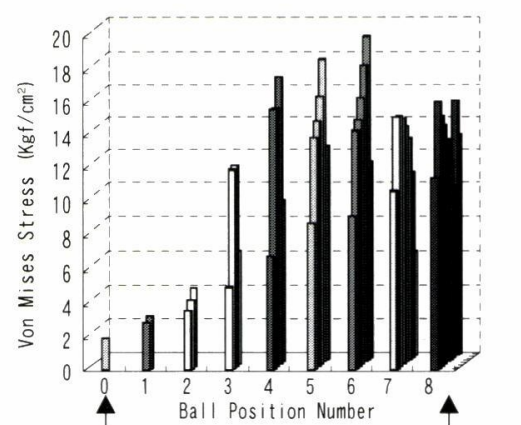

FC-BGA Center

Chip Edge

(c) : Tensile Stress of AL sample

Fig. 13 Stress distribution of Z-axis by $1 / 8$ mode of 1848 pin FC-BGA

を行う際には, 実装直後の反り矯正で発生した初期残留歪 みをも考慮する必要がある ${ }^{10)} 。$

\section{4. リワークの実装信頼性への影響}

\section{1 実装信頼性結果}

低剛性の L タイプ FC-BGAを実装したリワークなしのA ボードとリワークありのBボードを用い, リワークの実装 信頼性への影響を評価した。評価仕様はFig. 2 に示す $\mathrm{AL}$ （リワークなし）とBL（リワークあり）である。AL仕様は 完全にリワークなしで, BL 仕様はFig. 2 の $5 \mathrm{~mm}$ 間隔で搭 載されているNo. 1 No. 8のうち, No. 5 No.8の FC-BGA をリワークした後, リワークなしのNo. 1 No. 4の評価を 行った。試験結果はFig. 4 に示したように，特に，0.1\% Failureの初期寿命について, AL 仕様の1435サイクルに対 し， BL 仕様は 528 サイクルに劣化している。リワークあり ボードに搭載した FC-BGAは, リワークの影響で信頼性が 劣化している。

\section{2 リワークによる劣化の原因分析}

リワークによる劣化原因を分析するため, リワーク中の 温度分布測定を行った。Fig. 14 はFig. 2 に示す No. 5 位置の FC-BGAをリワークするときのボード温度面分布の測定結 果である。加熱温度 $225^{\circ} \mathrm{C}$ でリワークしているNo. 5 の FCBGAに隣接するNo. 3 の FC-BGA 温度は, パッケージ全体 がはんだ溶融温度の $183^{\circ} \mathrm{C}$ 以上に達しており, リワーク中 にBL 仕様の FC-BGA (No. 1 No. 4)の一部ははんだボールの 再溶融が発生しているとわかった。これは，5 $\mathrm{mm}$ 間隔で 高密度実装を行っていることより, リワーク時の熱の影響 を受けているためと考えられる。

この再溶融によるFC-BGAへの影響を確認するため, AL 仕様と BL 仕様について, No. 3 の FC-BGA のパッド位置で の断面観察を行った。結果を Fig. 15に示す。ボードパッド 位置に関しては, $\mathrm{AL}$ と BL仕様とも差がない。一方，FC$\mathrm{BGA}$ パッド位置に関しては, リワークなしの AL仕様は左 右対称であるが, リワークありの BL 仕様では, リワーク されたNo. 5 に近い端部の方が約 $90 \mu \mathrm{m}$ 高くなっていること

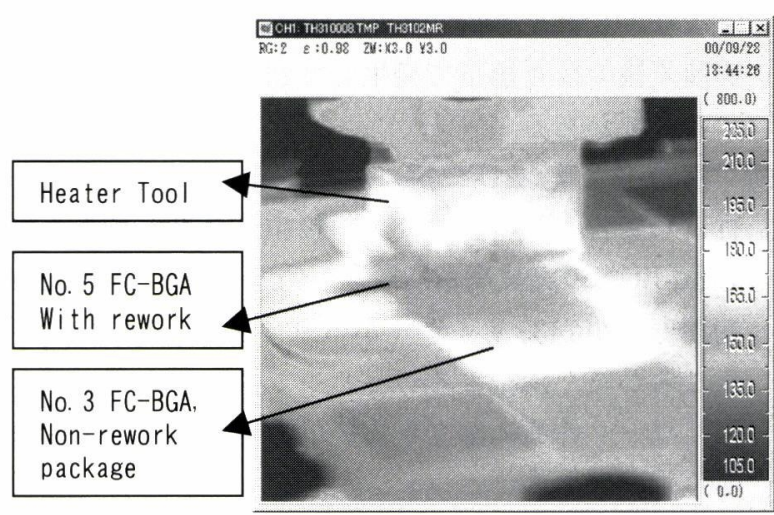

Fig. 14 Heat distribution at the reworking process for 1848 pin L type FC-BGA

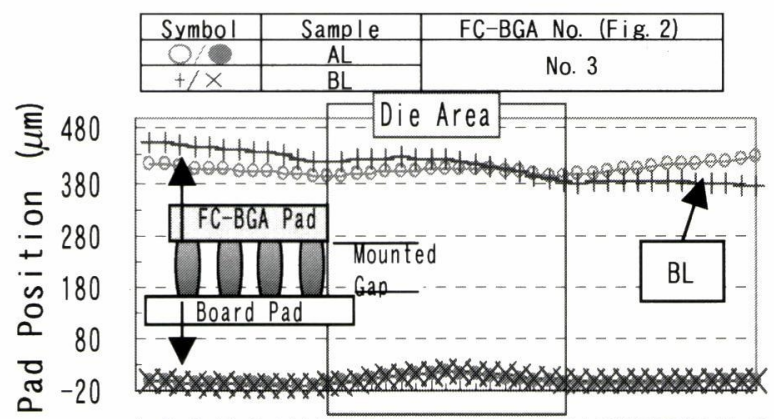

135791113151719212325272931333537394143

Ball Position Number

Fig. 15 Pad position of board and FC-BGA for the No.3 of $A L$ and $B L$ sample

がわかった。

以上より,リワークありボードに搭載した FC-BGAでの 信頼性の劣化は, リワーク熱の影響ではんだボールが再溶 融され, 実装高さの左右のバランスが崩れ, 高さが低く なった方に高い応力が集中したためと推定している。

\section{5. 結 論}

FC-BGAパッケージの高密度実装の温度サイクル信頼性 に及ぼす影響について調查した。今回の結果より, 以下の 内容が検証された。 
(1) FC-BGAの温度サイクルでの最初破壊は，チップ外 周領域の直下にあるはんだボールの FC-BGA 側のはん だ疲労破断である。破壊クラックはFC-BGA 中心向き の内側から発生し, 外側向きへ偏心円状に進展してい <。

（2） FC-BGAの温度サイクル信頼性での特性寿命は, 高 剛性タイプの方が低剛性タイプより長く, 4151 サイク ルである。パッヶージ剛性を高めることで, はんだ ボール凝固時の拘束力による FC-BGA 実装直後の反り 矯正量が小さく，信頼性を向上することができる。

(3) FC-BGA反りの変化に依存するZ方向の応力は, 最 大箇所が試験での破壊箇所と一致し, 破壊の主因と考 えられる。今後, FC-BGA信頼性予測において，精度 をよりよくするため, 相当歪み範囲を解析する際には, 実装直後の反り矯正で発生した初期残留歪みをも考慮 する必要がある。

(4) 高密度で実装したFC-BGAに対して, リワークを 行った場合，熱の影響で，隣接するリワークを行わな いFC-BGAの実装高さに傾きが発生し，0.1\% Failureの 初期寿命が 1435 サイクルから 528 サイクルまで低下し たころから，隣接するパッケージへの熱影響に配慮し たリワーク作業の確立が実装信頼性の劣化防止の観点 から重要である。

(2002.11.6-受理)

\section{文献}

1) E. C. Ahn and T. J. Cho, et al.: "Reliability of Flip Chip BGA Package on Organic Substrate", Proc $49^{\text {th }}$ Electronic Compo- nents and Technology Conf., pp. 1215-1220, 2000

2）塚田 裕：“ビルドアップ配線板入門”, 日刊工業新聞社, pp. 101-139, 1998.4

3) 呉 強, 岡田真喜雄, 他: “FC-BGA無電解 Ni/Auめっき パッドに対するはんだボール接合の技術開発”, 溶接学会全 国大会講演概要第65集, pp. 328-329, 1999.

4) Y. Tomita and Q. Wu, et al.: "Advanced Surface Plating on the Organic FC-BGA Package", Proc $50^{\text {th }}$ Electronic Components and Technology Conf., pp. 861-867, 2000

5) Y. Li, J. Xie, T. Verma and V. Wang: "Reliability Study of Highpin-count Flip-Chip BGA", Proc $50^{\text {th }}$ Electronic Components and Technology Conf., pp. 276-280, 2001

6) 大塚寛治, 宇佐美 保: “半導体パッケージング工学”, 日 経 BP 社, pp. 285-288, 1997.1

7) X. Zhang and S.-W. R. Lee: "Critical Issues in Computational Modeling and Fatigue Life Analysis for PBGA Solder Joints", The International Journal of Microcircuits and Electronic Packaging, Vol. 21, No. 3, Third Quarter, pp. 253-261, 1998

8) 塚田 裕： “フリップチップ技術”, 日刊工業新聞社, pp. 25-68, 2000.5

9) J. H. Lau: "Effects of Microvia Build-up Layers on the Solder Joint Reliability of a Wafer Level Chip Scale Package (WLCSP)", Proc $50^{\text {th }}$ Electronic Components and Technology Conf., pp. 1207-1215, 2001

10) 酒井秀久, 他: “BGAはんだ接合部の形状予測と残留応力 評価”, エレクトロニクス実装学会誌, Vol. 4, No.7, pp. 581-589, 2001.11 